\title{
Application of Contemporary Architecture in the Transfer Hub High Land Borobudur Building
}

\author{
Andiyan Andiyan,", Tita Cardiah ${ }^{2}$ \\ ${ }^{1}$ Department of Architecture, Faculty of Science and Engineering, Universitas Faletehan, Bandung, West Java, Indonesia \\ ${ }^{2}$ Interior Design, School of Creative Industries, Telkom University, Bandung, West Java, Indonesia
}

Received May 30, 2021; Revised November 10, 2021; Accepted November 21, 2021

\section{Cite This Paper in the following Citation Styles}

(a): [1] Andiyan Andiyan, Tita Cardiah, "Application of Contemporary Architecture in the Transfer Hub High Land Borobudur Building," Civil Engineering and Architecture, Vol. 9, No. 7, pp. 2353 - 2361, 2021. DOI: 10.13189/cea.2021.090722.

(b): Andiyan Andiyan, Tita Cardiah (2021). Application of Contemporary Architecture in the Transfer Hub High Land Borobudur Building. Civil Engineering and Architecture, 9(7), 2353 - 2361. DOI: 10.13189/cea.2021.090722.

Copyright $\bigcirc 2021$ by authors, all rights reserved. Authors agree that this article remains permanently open access under the terms of the Creative Commons Attribution License 4.0 International License

\begin{abstract}
This study aims to provide a supporting facility for the Borobudur Highland region in the Nglinggo-Sedayu Gate portion that will serve as a public transportation/transfer hub for the Borobudur Highland tourism area. This phase of research employs a combination of methods: site survey, primary and secondary data gathering, review of literature, precedents, and current comparative studies, data processing, and idea generation. According to the findings, the Transfer Hub building idea is Contemporary Architecture, which blends two architectural styles: modern architecture and $\mathrm{Neo}$ Vernacular, in which modern architecture incorporates contemporary features. In contrast, Neo Vernacular is more cultural, as shown by the Transfer Hub building's façade featuring the "Sekar Jagad" Batik motif. Hence, it is ideal for attractive natural forest landscapes and curvy terrain that present difficulties and selling points for the transfer hub building. Additionally, it is distinctive in transportation infrastructure in the Borobudur Highlands region that leads to the Transfer Hub. In conclusion, the Transfer Hub building supports and complements the Borobudur Highland infrastructure. The modern architectural approach to the Transfer Hub building adds value to the area's views and mode of transportation.
\end{abstract}

Keywords Transfer Hub, Borobudur, Highland, Extreme, Contemporary Architecture

\section{Introduction}

The Indonesian government is confronted with several issues relating to developing tourism regions, both domestic and international. The Borobudur Authority Implementing Agency will be referred to in the future as the Borobudur Authority Agency (BOB), which was established according to Presidential Regulation Number 46 of 2017. Borobudur Authority Agency (BOB) was established as a work unit under the Ministry of Tourism of the Republic of Indonesia by Minister of Tourism Regulation No. 10 of 2017. Borobudur Authority Agency (BOB) manages 309 hectares in Central Java's Menoreh Hills, Purworejo Regency. This area will develop into a regional economic engine and a new tourist attraction, complementing Borobudur Temple's status as one of Indonesia's top tourist sites.

The research focuses on the Nglinggo-Sedayu Gate segment, which supports the Borobudur Highlands tourism area's entire public and private transportation infrastructure at the Transfer Hub. A centralized parking lot serving as an orientation center is required in the Borobudur Highland region to facilitate natural tourism.

Research [1] aimed to investigate the connection between parking perceptions and beach attendance trends in North Carolina. The data was gathered through a systematic face-to-face interview ( $\mathrm{n} 14$ 1384) in a semi-structured format in several coastal locations throughout the state, as well as a random telephone survey (n 14 1877) of North Carolina residents who live in coastal counties that are 120 miles or less from the ocean. 
The findings indicated that beach visitors' perceptions of parking problems did not match the actual parking availability. Additionally, parking perceptions were not shown to be highly correlated with visitor patterns. The consequences for management are addressed — subsequent research by [2]. The study's findings show that eco-efficiency has been improving steadily over time. While pure technical efficiency is more important than scale efficiency, eco-efficiency is more important than pure technical efficiency. The research found four factors that affect the quality of information sharing. To further understand the nature of this interaction, a knowledge intermediary process model was created [3].

The significance of this study is to facilitate the implementation of the Borobudur destination's development, the Ministry of Tourism established the Borobudur Tourism Area Management Authority Agency (Borobudur Authority Agency/BOB) by Presidential Regulation No. 46 of 2017. The purpose of the Nglinggo-Sedayu Gate section on the arrangement of buildings and supporting facilities is to provide technical planning documents for the implementation of the construction of buildings and supporting facilities in the Borobudur Highland area, including the selection of the Nglinggo-Sedayu Gate as a guideline for construction [4]. The unique aspect of this study is the researcher's perspective on the methods and ideas used in the Transfer Hub construction. The concept is to use contemporary architecture, which incorporates a variety of styles [5]. The building's bulk is designed in a modern architectural style that incorporates glass, steel columns and beams, corporate metal on the entrance's front façade, and other contemporary materials. Incorporating vernacular architectural styles into a traditional Javanese roof idea, namely the "Joglo" [6]. Additionally, the idea of the aerobic system is used. On the facade, stopsol glass components act as a glare reduction. [7]. Additionally, the eco-architectural style is reflected in the positioning of the building mass by the contour slope [8].

This study aims to aid in the preservation of the Borobudur Highlands' Nglinggo-Sedayu Gate portion. To promote the growth of Borobudur, the Ministry of Tourism created the Borobudur Tourism Area Management Authority Agency (Borobudur Authority Agency/BOB) by Presidential Regulation No. 46 of 2017. However, technically it still requires a level of awareness from the community to carry out the health protocol while in the mosque environment [9].

\section{Research Methods}

Descriptive analysis was utilized as the study technique. The field's current status was compared to the theory in this study [10], performing field surveys via interviews and data collection, including conceptual drawings, working drawings, and photographs. It was then compared to concepts for residential buildings, interior spatial arrangement, and contoured terrain to arrive at a conclusion that may be considered while constructing the steep contoured ground [11]. A summary of the villages of Benowo, Cacaban Kidul, Cacaban Lor, and Pekacangan in Bener District and Sedayu in Loano District, Purworejo Regency, as proponents of the Highland Borobudur Transfer Hub Building. The literature study uncovered theoretical underpinnings, design standards, planning, and design policies (through field surveys, online searches, and literature studies), as well as non-physical physical circumstances and geography [12]. Additionally, a comparison study comparing data from field investigations and comparative studies with literature studies were conducted.

Table 1. The tool used for measurements

\begin{tabular}{|c|c|c|c|}
\hline No & Tool's name & Lots & Information \\
\hline 1 & Total Station (TS) & 2 & The primary means of measurement \\
\hline 2 & Theodolite (T0) & 3 & The primary tool of measurement \\
\hline 3 & Prism TS & 4 & For both situation points and polygons \\
\hline 4 & Pillar of Prism & 4 & Where to install TS prisms \\
\hline 5 & Tripod & 5 & A place to put TS \\
\hline 6 & Thumbtack & Sufficiently & As a sign of the point of the establishment of Total Station and Theodolite \\
\hline 7 & Spray Paint / Pylox & 15 & Marker \\
\hline 8 & Hammer & 5 & Install nails \\
\hline 9 & Marker & 20 & Stake name marker \\
\hline 10 & Usual Meter & 5 & Measure the height of the primary tool \\
\hline 11 & Camera & 2 & For taking field photo documentation \\
\hline 12 & Stationery (Pen + paper) & Sufficiently & Mark at the point where the measurement is \\
\hline 13 & Radio HT & 4 & Long-distance communication media \\
\hline 14 & Laptop & 2 & For processing data \\
\hline
\end{tabular}


A contour line is an imaginary line drawn on the ground that links points of equal height, or it is a continuous line drawn on a map that depicts moments of equal size. [13].

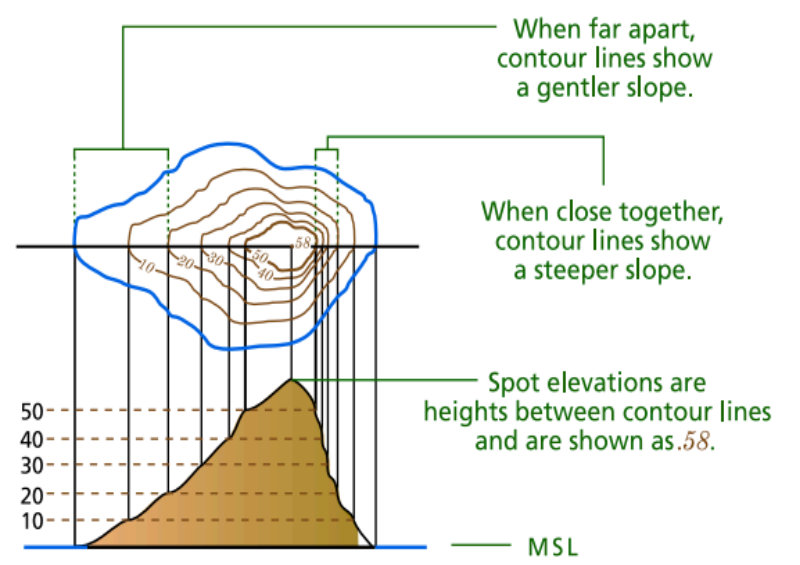

Figure 1. Examples of contours on the map

- If the layout is appropriate, a house constructed on the curved ground will be rich in spatial creativity.

- Utilizing land on a curved surface creates space that may be concealed amid other places. For instance, a three-story home will be seen from all angles from just one level.

- Shelter on uneven ground is peculiar to a one-story home (without an upper floor) situated on an irregularly shaped plot of land.

- Another distinguishing feature that does not exist on flat terrain is the scenery. The front of the building will be divided into two sides on this property. The resultant vision is much more pleasurable.

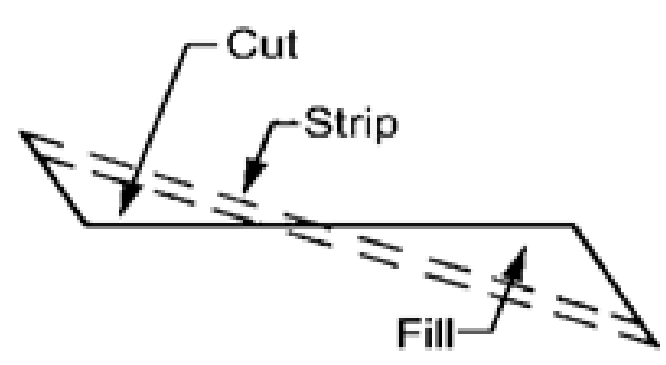

Figure 2. Contoured Land Engineering

One of the treatments is the cut and fill method to minimize the danger of soil disposal on contoured land, as shown in Figure 2.

We must pay close attention to the comparison when processing cut and fill since cut and fill must have a relatively small difference. The formula is shown in Figure 3 above.

Borobudur is situated in the Menoreh Hills, administratively in Benowa, Cacaban Kidul, Cacaban Lor, and Peguling in Bener District, and Sedayu Village in Loano District, Purworejo Regency. This region is close to the Kulon Progo and Magelang regencies. The terrain in the Menoreh Hills region is very severe, ranging from $15^{\circ}$ to $40^{\circ}$ or $30 \%$ to $80 \%$. Every project has a deadline so that completion is not late, but every project does not always go according to schedule14].

North: Salaman District (Magelang Regency)

South: Samigaluh District (Kulon Progo Regency)

East: Salaman District and Samigaluh District

West: Bener District and Loano District (Purworejo Regency)

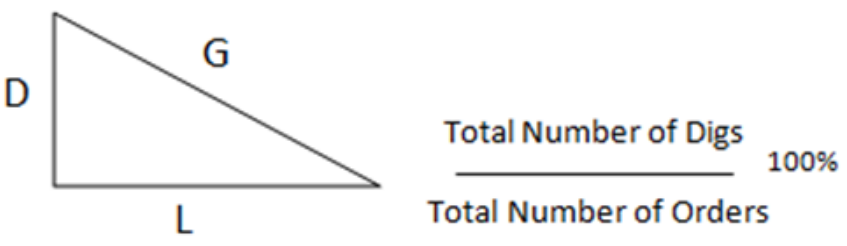

\section{Basic Grading Formulas:}

- $\mathrm{D}=$ The difference in height between the land faces

- $\mathrm{L}=$ Length or distance

- $\mathrm{G}=$ Slope or slope of land surface

Figure 3. Basic Grading Formulas 


\section{Results and Discussion}

Borobudur Highland Tourism Area has excellent potential for development as a tourism center for Menoreh Hills tourism activities. To become a magnet for new tourism destinations in the wider region, Borobudur Highland must create more tourist attractions that complement and synergize with current tourist attractions, thus balancing the appeal of other tourist destinations [15] in Central Java and Yogyakarta.

Table 2. Land conditions in Borobudur highland

\begin{tabular}{|c|l|ll|}
\hline $\begin{array}{c}\text { Land } \\
\text { Conditions }\end{array}$ & $:$ & $\begin{array}{l}\text { State pine forest, whose management } \\
\text { is carried out by Perum Perhutani. }\end{array}$ \\
\hline Topography & $:$ & $\begin{array}{l}\text { Forest status consists of production } \\
\text { forest and limited production forest. }\end{array}$ \\
\hline - & & $\begin{array}{l}\text { Altitude } 400-1000 \mathrm{~m} \text { above sea level } \\
\text { Hills with steep slopes \& some } \\
\text { relatively flat } \\
\text { The highest area in the east of the area } \\
\text { The height of the will. West heading } \\
\text { north \& south getting lower }\end{array}$ \\
\hline & $:$ & $\begin{array}{l}\text { Slopes }>15^{\circ} \text { and }>40^{\circ} \\
\text { The relatively safe area to be built is } \\
\text { scattered place of } 189.67 \text { hectares spread } \\
\text { A placel } \\
\text { throughout the region, relatively safe } \\
\text { to be developed with specific } \\
\text { engineering/security technology. }\end{array}$ \\
\hline
\end{tabular}

\section{Road Circulation}

\begin{tabular}{|c|c|c|c|}
\hline $\begin{array}{c}\text { East Side of the } \\
\text { Area }\end{array}$ & : & $\begin{array}{c}\text { Pagerharjo Village } \\
\text { Nglinggo, Kulon Progo } \\
\text { Regency }\end{array}$ & 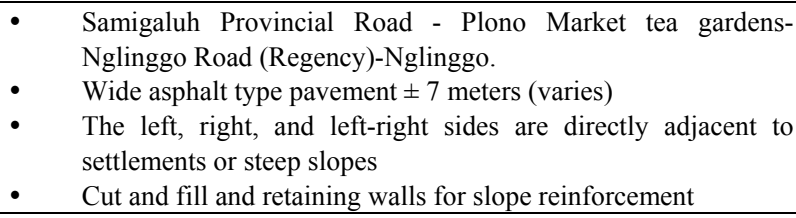 \\
\hline $\begin{array}{l}\text { West Side of } \\
\text { the Area }\end{array}$ & : & $\begin{array}{c}\text { Sedayu Village, Loano } \\
\text { District, Purworejo } \\
\text { Regency }\end{array}$ & $\begin{array}{l}\text { - } \\
\text { - } \quad \text { An asphalt pavement and partly concrete pavement. } \\
\text { - The slope of the Sedayu access road varies, and some are more } \\
\text { than } 10 \% \text {. } \\
\text { - The left, right, and left, and right sides are directly adjacent to } \\
\text { settlements or steep slopes } \\
\text { - } \quad \text { Cut and fill and retaining walls for slope reinforcement } \\
\text { Another alternative for achievement, especially for large } \\
\text { vehicles (buses), is through Sedayu Village, followed by small } \\
\text { cars to the Borobudur Highland area. }\end{array}$ \\
\hline $\begin{array}{c}\text { North Side of } \\
\text { the Area }\end{array}$ & : & $\begin{array}{c}\text { Kalirejo Village, Salaman, } \\
\text { Magelang Regency }\end{array}$ & $\begin{array}{l}\text { Kalirejo Magelang Road -Cacaban Lor, Bener District, } \\
\text { Purworejo } \\
\text { Asphalt pavement with a road width of } \pm 7 \text { meters, varying from } \\
\text { Magelang to Purworejo. } \\
\text { The road can be passed by buses and is directly connected to the } \\
\text { Borobudur Temple area. } \\
\text { Based on the potential, the area entrance plan that can be built in } \\
\text { the first stage is the Pagerharjo door, and at the next stage, the } \\
\text { Sedayu door can be developed. }\end{array}$ \\
\hline
\end{tabular}

Table 3. Road Circulation

\begin{tabular}{|c|c|c|c|}
\hline Internal area & $:$ & $\bullet$ & $\begin{array}{l}\text { Offroad roads opened by the people of } \\
\text { Nglinggo-Pagerharjo, } \\
\text { Width Varies from } 2.5 \text { to } 3 \text { meters and } \\
\text { can only be passed by } 4 \text { WD vehicles. }\end{array}$ \\
\hline External area & $:$ & $\begin{array}{l}\text { The road connects the surrounding } \\
\text { villages (Pagerharjo Village, Sedayu } \\
\text { Village, and Benowo Village). } \\
\text { The road connects Magelang, } \\
\text { Purworejo, and Borobudur areas. } \\
\text { The difficulty level of achieving is } \\
\text { relatively high because the slope of the } \\
\text { road varies, and some are more than } \\
10 \% \text {. }\end{array}$ \\
\end{tabular}

Accessibility towards the Borobudur Highland Area

The route to the Borobudur Highland area connects different areas with transportation centers such as airports or terminals through provincial and regency highways. The webpage may be accessed from the side, namely [16]:

\section{The design concept of the Transfer Hub Building}

The Transfer Hub is 259 ha, particularly in the HPL, a 50 ha BOB area. The Transfer Hub, the area's primary structure, is a symbol of Highland Borobudur. As an information center, the public may learn more about the services available in the Highland Borobudur region. Additionally, the Highland Borobudur region includes support structures such as the UMKM Center, the Transfer Hub, and the Amphitheater [17]. 


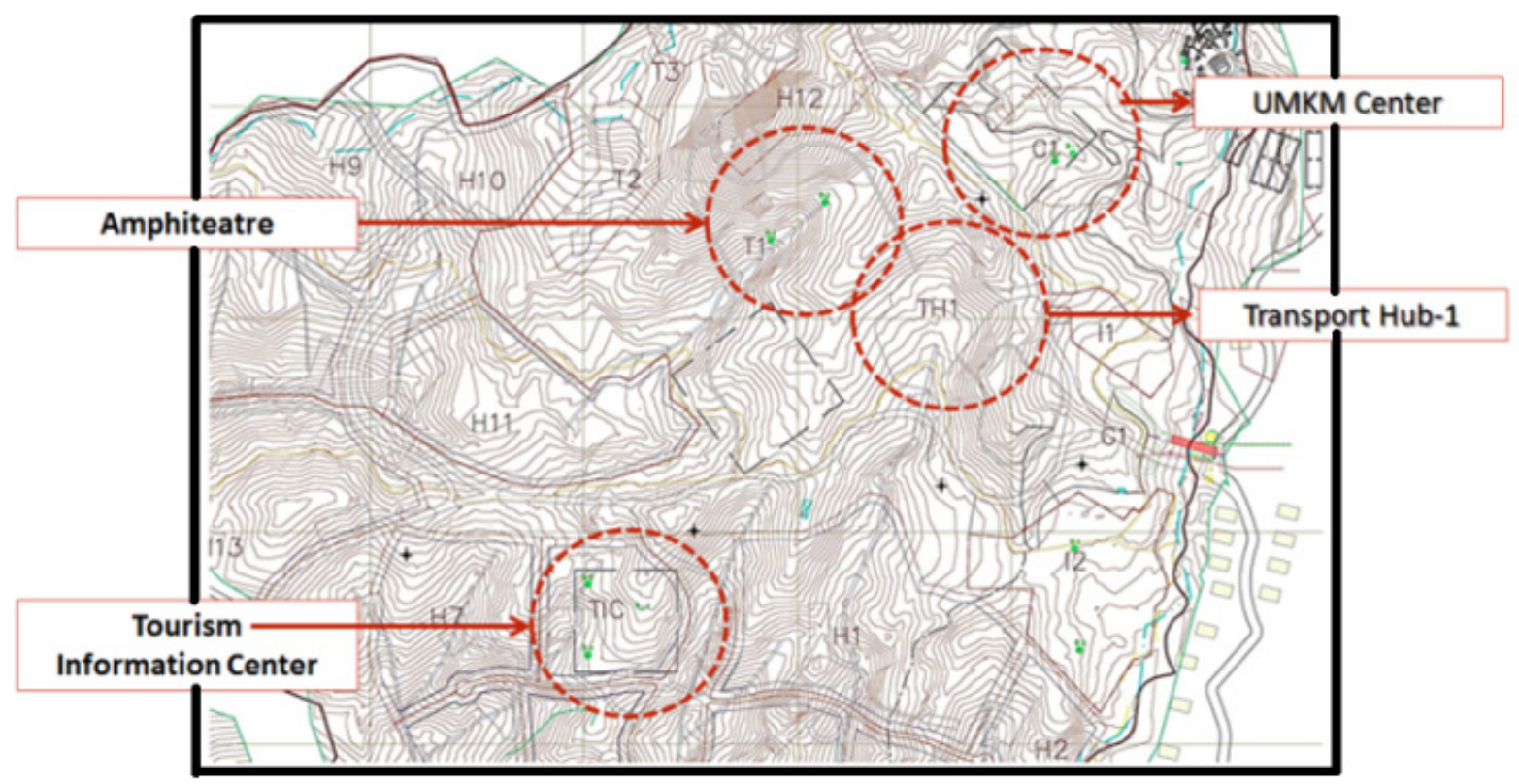

Figure 4. Existing Tourism Topographic Map in the Borobudur Highland Area and its surroundings

Table 4. Requirements for the dimensions of Transfer Hub land \& building

\begin{tabular}{|c|c|c|c|c|c|c|}
\hline Building Functions & Plot area $\left(\mathbf{m}^{2}\right)$ & $\begin{array}{c}\text { \% } \\
\text { BCR }\end{array}$ & $\begin{array}{c}\text { \% } \\
\text { Green }\end{array}$ & $\begin{array}{c}\text { Large Floor } \\
\text { Basic }\left(\mathbf{m}^{2}\right)\end{array}$ & $\begin{array}{c}\text { Floor Area } \\
\text { Ratio (FAR) }\end{array}$ & Plot Borders (m) \\
\hline Transfer Hub & 20733 & 10 & 90 & 18660 & 0,2 & 2073 \\
\hline
\end{tabular}

The Zoning of the Borobudur Highland region, where the Transfer Hub serves as the hub for all means of transportation that convey visitors, is shown in Figure 4.

The Transfer Hub Building's design idea is guided by the following requirements, notably [18]:

\section{Principles of the Transfer Hub}

In terminology, the Transfer Hub is:

a Transfer hub service facilities that are accurate and up-to-date are available to anybody who needs them.

b A location for marketing aimed at increasing the number of visits and the duration of stay of visitors.

\section{The function of Transfer Hub Building}

The Transfer Hub's functions are defined in the Borobudur High Land Master Plan.:

a The central center/hub of Borobudur Highland

b Information center about:

- Accommodation /resorts

- Tourist activities can be done within the area.

c The Transfer Hub Region is responsible for tour packages both inside and beyond the Borobudur Highland area.

d According to this and the requirements of Minister of Tourism Regulation No. 5 of 2019 on Technical Operational Guidance for the Physical DAK for Tourism, the Transfer Hub's activities may be classified into four categories: promotion, travel advice and assistance, and education, and sales [19].

\section{Physical Dimensions of Land \& Building}

The master plan states that the BCR of this Transfer Hub lot is $20 \%$. However, based on the master plan's instructions, the highest $\mathrm{BCR}$ of the lots that may be allowed is $25 \%$ [20].

\section{Location}

Because the Transfer Hub is the Exclusive Resort Zone's sole semi-public function, the plot and building design ideas will be as follows[21]:

a) Exclusive but at one with the natural surroundings, by using:

1) Glass material in the building envelope.

2) Contour preservation and cut \& fill minimization

3) Arrangement of vegetation elements

b) Eye-catching/vocal point between resort hotels and lodge buildings in the vicinity.

The following figure illustrates the placement of the Transfer Hub based on the criteria specified in the Master Plan document and the findings of field surveys [22]. 
The arrangement of the building mass is necessary to prevent the formation of a monolith or a single group inside a parcel, which may result in a massive form and block the view of another building toward a specific item [23].

- It is a mass arrangement of buildings based on the idea of a platform that avoids direct contact with the earth.

- Several platforms are arranged symmetrically or asymmetrically connected by the boardwalk

- The building mass is often square. Other mass shapes may be used as long as they provide a minimal purpose.

- The distance between building masses is at least 6 meters.

- The mass and height configuration of the building must provide visibility or "Stolen Vista."

- Connectivity between buildings must be simple and easy to read by building users.

Mass design and building structure must be uncomplicated and straightforward.

\section{Utilization of Hills' Slopes}

- Arrangement on hilly slopes is only permitted in hilly areas with a maximum gradient of $25 \%$.

- Hill slopes can only be used for buildings with "Light Structure and Light Load or Non-Massive Development."

- All arrangements on hilly slopes such as buildings, swimming pools, and others must go through in-depth soil geotechnical studies and be approved by the Design Committee.

- The use of a structural system should not alter the landscape of hilly areas.

- Every arrangement on hilly slopes must be considered and must have an excellent structural and drainage system to protect the building from earthquakes, water, and soil erosion.

- The maximum height of the building is two floors or $10 \mathrm{~m}$ from the ground floor surface to the top surface of the structural beam ring.

- The highest level of the roof and the roof of a building must not exceed the highest level of the hilly area where the building stands.

Greening on hilly slopes must be done through a well-planned and well-planned landscape.

Transfer Hub building with a contemporary architectural approach where local culture elements are on the facade, namely "Batik Sekar Jagad" typical of Jogja and the combination of modern materials in the building covered with stopsol glass as we can see in Figure 5.

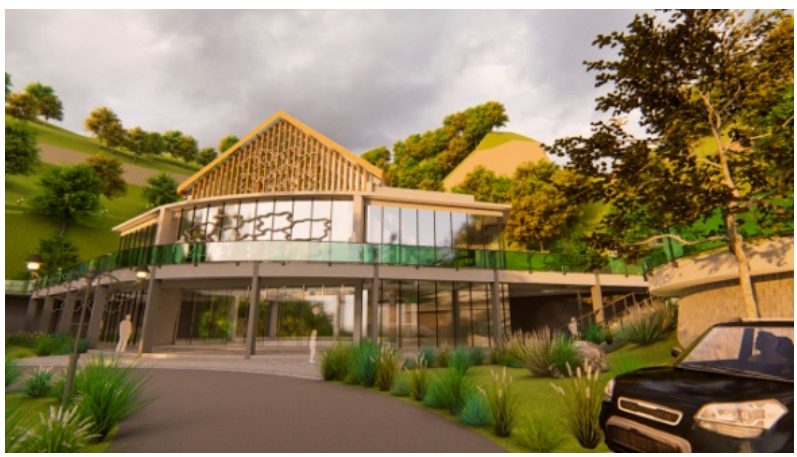

Figure 5. Section-1 Building Transfer Hub

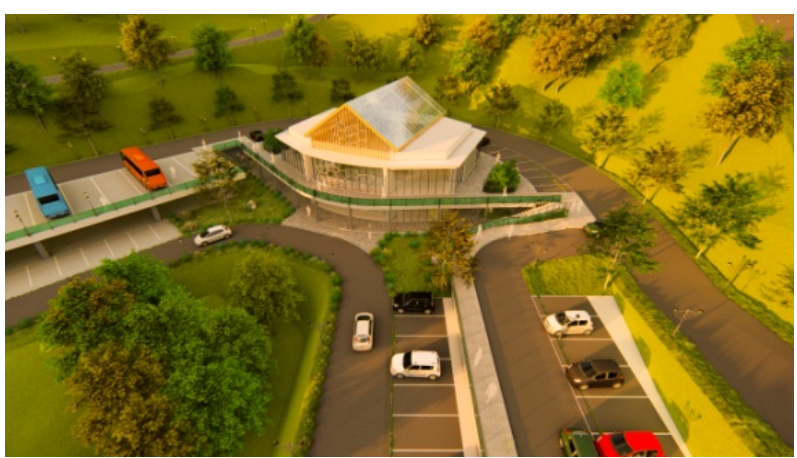

Figure 6. Section-2 Transfer Hub Building

The Transfer Hub is a center for gathering modes of transportation, whether private or public. Everything is centralized in the Transfer Hub, as shown in the bird's eye image in Figure 6.

\section{Application of Local (Joglo) and Non-Local (Modern) Architecture Acculturation}

By using conventional and contemporary architectural components and incorporating Javanese cultural aspects, it enhances the identity and character of traditional Joglo architecture in the region. Later on, it is anticipated that it will enhance the aesthetic values of identity and the historic architectural character of Joglo [24].

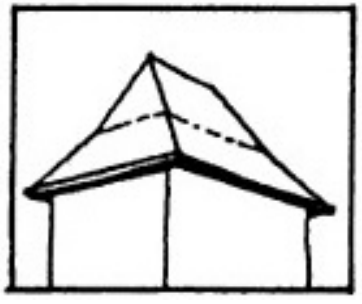

(a)

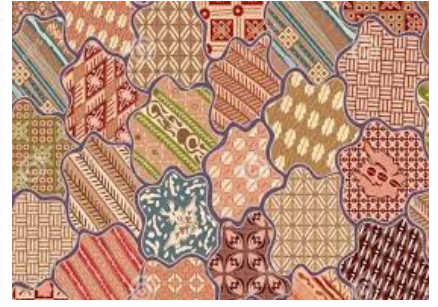

(b)
Figure 7. (a) The typical Javanese roof "Joglo Limasan Lawak" is applied to the Transfer Hub Roof. (b) The motif of "Batik Sekajar Jagad" is applied to the vertical elements of the building's facade. 


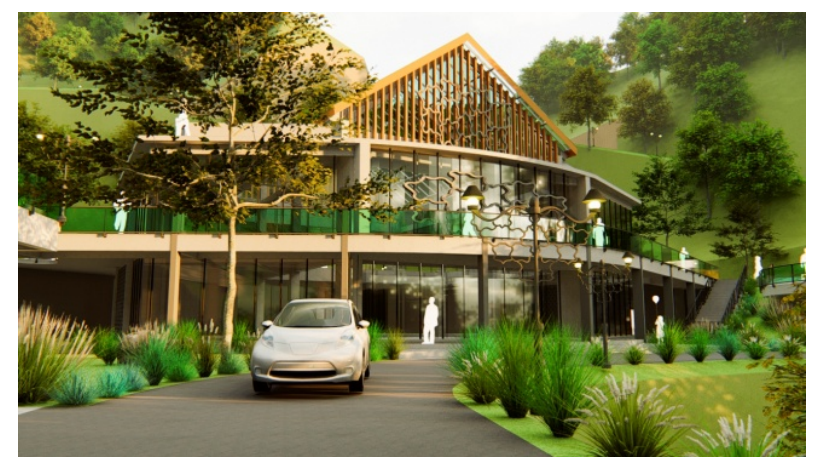

Figure 8. The view from before the scale of the human eye

Transfer Hub building with a contemporary architectural approach where local culture elements are on the facade, namely "Batik Sekar Jagad" typical of Jogja and the combination of modern materials in the building covered with stop sol glass in Figure 8.

Transfer hub building approach with contemporary architecture:

- Application of traditional Joglo architectural identity and modern architecture:

- Roofs, column posts, wall motifs, natural colors, ornaments.

- Building composition

- Head, body, legs

- Material

- $\quad$ Natural stone, glass, wood

- Traditional Joglo architectural characters:

- Simple, use of ornament, characteristic of natural colors.

- Application to buildings in Borobudur Highland:

- Entrance gate, Tourism Information Center, and several other types of commercial buildings.

- Modification of the traditional Joglo architecture:

- Limited as long as it does not dominantly change the basic form.

- Materials that do not predominantly change the primary character.

Being able to enrich the aesthetic values of traditional Joglo architecture.

By visioning of Borobudur Highland, which is described in the concept of "culture and adventure ecotourism," the branding of the Borobudur Highland Tourism Area is as follows [25]:

"To become a natural, adventurous, and cultural tourism destination on an international scale with the principle of being sustainable as a tourism hub for the tourism area of Borobudur Temple in 2030."

Borobudur Highland's spatial characterization approach evokes the region's uniqueness and enhances its identity by emphasizing various zones within the territory. The more visually appealing a feature is, the more likely it will be remembered/understood by visitors [26]. As a result, the approach to defining this area's space will center on the visual elements of the site that provide meaning to visitors (a sense of place) [27].

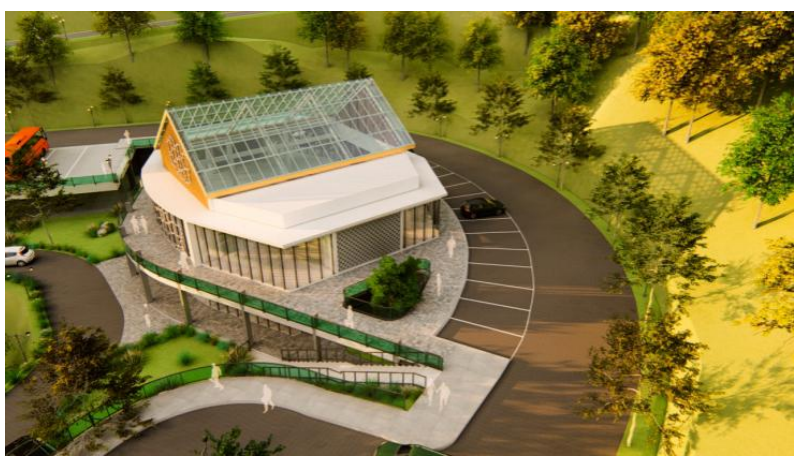

Figure 9. Bird's eye from the left

The Transfer Hub is a center for gathering modes of transportation, whether private or public. Everything is centralized in the Transfer Hub, as shown in the bird's eye image in Figure 9.

This reflective coating has a long-lasting endurance and quality, reflects light and heat, and delivers a rich touch of style while reducing air-conditioning needs [28]. The coating is applied on only one surface of the glass, and it consists of super silver and classic [29].

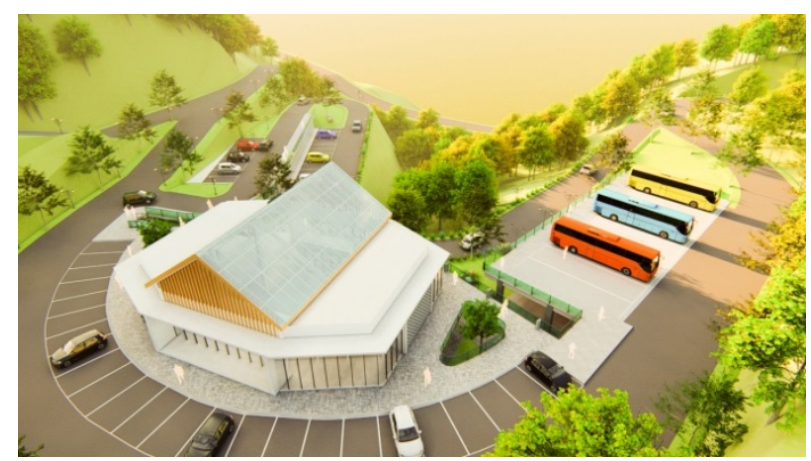

Figure 10. Bird's eye from the right

The Transfer Hub is a center for gathering modes of transportation, whether private or public. Everything is centralized in the Transfer Hub, as shown in the bird's eye image in Figure 10.

\section{Conclusion}

In conclusion, the Transfer Hub building serves as a backbone for the Borobudur Highland infrastructure. Its modern architectural style adds value in terms of vistas and modes of transportation in the region.

Structuring the mass of the building is necessary to prevent a monolithic or single mass in a single parcel, which may result in a gigantic figure and block the view of another building towards a specific item. 


\section{Acknowledgments}

We would like to express our gratitude to the Borobudur Authority Agency (BOB) for participating in this research and supplying primary and secondary data that ensured the study's success.

\section{REFERENCES}

[1] A. Snider, S. Luo, J. Hill, and J. Herstine, "Ocean \& Coastal Management Perceptions of availability of beach parking and access as predictors of coastal tourism," Ocean Coast. Manag., vol. 105, pp. 48-55, 2015, doi: 10.1016/j.ocecoa man.2014.12.022.

[2] H. Peng et al., "Eco-efficiency and its determinants at a tourism destination: A case study of Huangshan National Park, China," Tour. Manag., vol. 60, pp. 201-211, 2017, doi: 10.1016/j.tourman.2016.12.005.

[3] K. K. Charles Jencks, Theories And Manifestoes Of Contemporary Architecture. London: Cerver, Fransisco, 1981.

[4] F. Al Tawayha, "Contribution of the vernacular architecture to the sustainability: A comparative study between the contemporary areas and the old quarter of a Mediterranean city," Sustain., vol. 11, no. 3, 2019, doi: 10.3390/su110308 96.

[5] P. J. Tabb, The greening of architecture: A critical history and survey of contemporary sustainable architecture and urban design. 2014.

[6] G. Ioppolo, "From coastal management to environmental management: The sustainable eco-tourism program for the mid-western coast of Sardinia (Italy)," Land use policy, vol. 31, pp. 460-471, 2013, doi: 10.1016/j.landusepol.2012.08. 010 .

[7] B. Molnár, "Architecture and system design issues of contemporary Web-based Information Systems," SKIMA 2011 - 5th International Conference on Software, Knowledge Information, Industrial Management and Applications. pp. 33-39, 2011, doi: 10.1109/SKIMA.2011. 6089978.

[8] N. S. Muñoz, "From vernacular to contemporary: Kilwa (Tanzania) and albreda (the Gambia) tourist information centres," Vernacular and Earthen Architecture: Conservation and Sustainability - Proceedings of SOStierra2017 2017. pp. 693-698, 2018, [Online]. Available:

https://api.elsevier.com/content/abstract/scopus_id/850580 71786 .

[9] T. Cardiah, A. Andiyan, and A. Rahma, "Implementation of Health Protocols at Mosques during the Covid-19 Pandemic in the city of Bukittinggi," Rev. Int. Geogr. Educ., vol. 11, no. 5, pp. 3765-3771, 2021, doi: 10.48047/rigeo.11.05.260.

[10] Sugiyono, Qualitative Quantitative Research Methods and $R \& B$. Bandung: CV. Alfabeta, 2012.
[11] D. Ching, Architecture: Space \& Order. Bandung: Erlangga, 2008.

[12] Lexy J. Moleong, Qualitative Research Methodology. Bandung: PT Remaja posdakarya, 2000.

[13] R. Wulandari, "Perancangan Bandung Hotel Dan Resort, Pada Lahan Kontur J1. Terusan Sersan Bajuri, Desa Cihideung, Kelurahan Isola Kecamatan Sukasari, Kota Bandung Jawa Barat (SITE C).” Universitas Mercu Buana Jakarta, 2019.

[14] Andiyan Andiyan, R. M. Putra, G. D. Rembulan, and H. Tannady, "Construction Project Evaluation Using CPM-Crashing, CPM-PERT and CCPM for Minimize Project Delays," in Journal of Physics: Conference Series, 2021, vol. 1933, no. 1, p. 12096.

[15] G. Tiberghien, "Performance and visitors' perception of authenticity in eco-cultural tourism," Tour. Geogr., vol. 19, no. 2, pp. 287-300, 2017, doi: 10.1080/14616688.2017.12 85958 .

[16] D. A. Garcia, "Eco friendly service buildings and facilities for sustainable tourism and environmental awareness in protected areas," WIT Trans. Ecol. Environ., vol. 161, pp. 323-330, 2012, doi: 10.2495/ST120261.

[17] E. Schimbeck, Gagasan, bentuk, dan arsitektur. Prinsip-prinsip perancangan dalam arsitektur kontemporer. Bandung: Intermatra, 1988.

[18] J. E. Araña, C. J. León, M. M. Carballo, and S. Moreno Gil, "Designing tourist information offices: The role of the human factor," J. Travel Res., vol. 55, no. 6, pp. 764-773, 2016.

[19] H. Buijtendijk, "Eco-innovation for sustainable tourism transitions as a process of collaborative co-production: the case of a carbon management calculator for the Dutch travel industry," J. Sustain. Tour., vol. 26, no. 7, pp. 1222-1240, 2018, doi: 10.1080/09669582.2018.1433184.

[20] M. Alonso-Almeida, "Shedding light on eco-innovation in tourism: A critical analysis," Sustain., vol. 8, no. 12, 2016 , doi: $10.3390 / \mathrm{su} 8121262$.

[21] S. O. Lyu and H. Lee, "Preferences for tourist information centres in the ubiquitous information environment," Curr. Issues Tour., vol. 18, no. 11, pp. 1032-1047, 2015.

[22] R. A. Bay, "Predicting responses to contemporary environmental change using evolutionary response architectures," Am. Nat., vol. 189, no. 5, pp. 463-473, 2017, doi: 10.1086/691233.

[23] I. Martek, "The sustainability narrative in contemporary architecture: Falling short of building a sustainable future," Sustainability (Switzerland), vol. 10, no. 4. 2018, doi: 10.3390/su10040981.

[24] T. Wortmann, "Differentiating parametric design: Digital workflows in contemporary architecture and construction," Des. Stud., vol. 52, pp. 173-197, 2017, doi: 10.1016/j.destud.2017.05.004.

[25] I. D. Gede, A. Diasana, I. M. Adhika, A. Agung, and G. Agung, "Reviving Cultural Tourism in Kendran Bali Indonesia: Maintaining Traditional Architecture and Developing Community-based Tourism," Civil Engineering and Architecture, vol. 9, no. 2, pp. 328-338, 2021, doi: 10.13189/cea.2021.090206. 
[26] L. Hilberseimer, Contemporary Architecture the Roots and Trends. Chicago: Chicago, Il: PAul Theobald and Company, 1964.

[27] H. Peng, "Eco-efficiency and its determinants at a tourism destination: A case study of Huangshan National Park, China," Tour. Manag., vol. 60, pp. 201-211, 2017, doi: 10.1016/j.tourman.2016.12.005.
[28] R. Merli, "The impact of green practices in coastal tourism: An empirical investigation on an eco-labelled beach club," Int. J. Hosp. Manag., vol. 77, pp. 471-482, 2019, doi: 10.1016/j.ijhm.2018.08.011.

[29] Asensio, World of Contemporary Architecture. Germany: Konemann, 2005. 